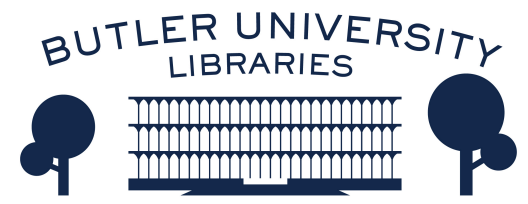

Booth

Volume 7 | Issue 3

Article 1

3-6-2015

\title{
The Beginning and the Beginning Again
}

Eric Paul

Follow this and additional works at: https://digitalcommons.butler.edu/booth

\section{Recommended Citation}

Paul, Eric (2015) "The Beginning and the Beginning Again," Booth: Vol. 7 : Iss. 3 , Article 1.

Retrieved from: https://digitalcommons.butler.edu/booth/vol7/iss3/1

This Article is brought to you for free and open access by Digital Commons @ Butler University. It has been accepted for inclusion in Booth by an authorized editor of Digital Commons @ Butler University. For more information, please contact digitalscholarship@butler.edu. 


\title{
The Beginning and the Beginning Again
}

\author{
Abstract \\ I stand in the bathroom doorway, gripping my Virginia Is For Lovers mug while the morning sickness \\ rushes through her like consumers through a box store on Black Friday. \\ Cover Page Footnote \\ The Beginning and the Beginning Again was originally published at Booth
}




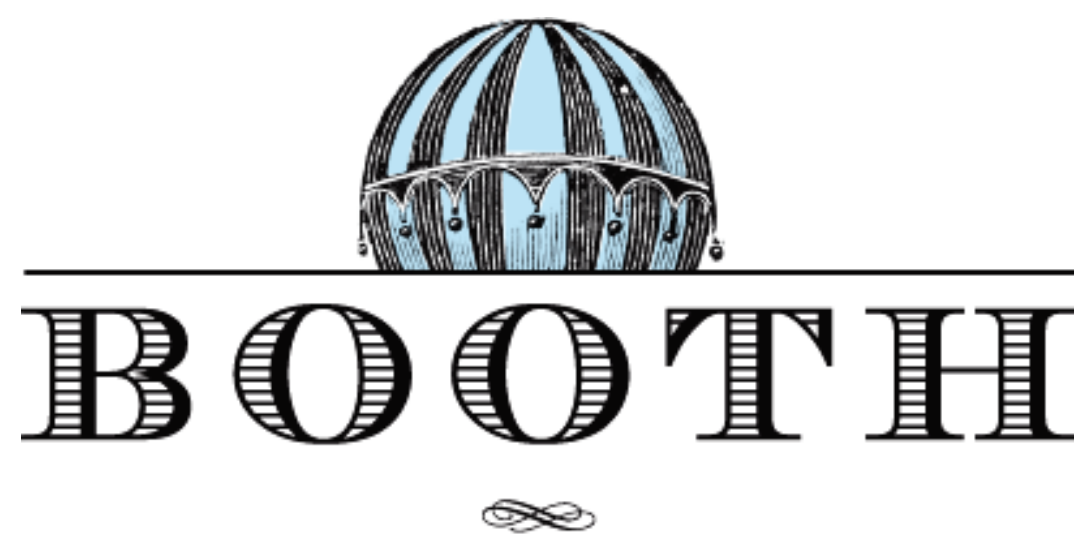

A JOURNAL

March 6, 2015

\title{
The Beginning and the Beginning Again
}

\author{
Fiction by Eric Paul
}

I stand in the bathroom doorway, gripping my Virginia Is For Lovers mug while the morning sickness rushes through her like consumers through a box store on Black Friday. I'm doing all the wrong things. I watch as she pukes up a bowling ball. Why the bowling ball? I ask. You're an asshole! she snaps. How can you forget? Our first date was at Lang's Bowlarama. I apologize, understanding that her insides are very outside of her these days. She crawls back into bed. I wait until she falls asleep before heading into the bathroom. I grab the bowling ball out of the toilet and think, This is going to be hard to swallow. Tomorrow, she will throw up a bouquet of flowers. That will go down more easily.

Eric Paul is a writer and musician from Providence, Rhode Island. He has been the lyricist and vocalist for the bands Arab On Radar and The Chinese Stars as well as his current band, Doomsday Student. In 2009 a collection of Eric's lyrics and poetry was released by Heartworm Press titled I Offered Myself As The Sea. Since then, he has released two chapbook and two spoken word releases. Eric holds a BFA in Philosophy from Rhode Island College and an MFA in Creative Writing from Fairleigh Dickinson University. His work has also appeared in Ninth Letter, Word Riot, Spork, Lunch Ticket, The Literary Review, and others. 